\title{
BEHAVIOURAL CHANGES WITH AGE IN A SAMPLE OF PAKISTANI ADOLESCENTS
}

\author{
Huzefa Jibril', Hafiz Noman Saleem², Syed Danish Naseem³ ${ }^{3}$ Karam Khan ${ }^{4}$, Aqal Khan ${ }^{5}$
}

1,2,3,4,5 MBBS, graduate Ziauddin University.

Correspondence: Huzefa Jibril. E-mail: huzefa.jibril@outlook.com

\begin{abstract}
Introduction: As adolescents move from being children to young adults, behavioural modifications occur during this transition period. Studies from other countries have shown decreasing physical activity and increasing use of alcohol and tobacco. Such studies have allowed interventions to be developed that have led to better outcomes. This study aims to identify areas of concern to allow target interventions to be developed.

Objectives: Identify behavioural changes that occur in adolescents as they progress through school.

Methods: A self administered questionnaire was developed consisting of 28 questions on various categories. 2 schools of Karachi were chosen and permission was obtained from the principal of the respective schools. The questionnaire was administered to students of grade 6, 8 and 10 in the classroom after obtaining informed consent.

Results: A total of 603 students participated in the study. 191 students were from grade 6, 197 were from grade 8 and 215 were from grade 10. Physical activity and healthy eating habits decreased moving from grade 6 to grade 10 . Increasing trends were seen in internet use, cigarette smoking and sheesha use. Parental involvement in their children's studying was less amongst students of grade 10 then students of grade 6 and grade 8 .

Conclusion: As indicated by previous studies adolescent behaviour seems to be becoming more unproductive as adolescents progress through school. Unhealthy eating habits, decreased physical activity and increased risky behaviour were seen in adolescents in higher grades. Some of this behaviour appear to get progressively worse as the student progresses through school while others occur at specific times.
\end{abstract}

Keywords: Adolescents, school, education, behaviour, public health.

\section{Introduction}

According to the World Health Organization (WHO) the adolescent age group is defined as individuals falling in the age bracket of between 10 and 19 years of age (1). During this period, as children transition through adolescence to become adults, psychological and behavioural modifications occur. Many of these changes appear to not only have a negative impact on the individual themselves, but also their peers (2). Furthermore they can also be carried on to adult life (3).

Research on adolescent behaviour has been conducted worldwide. In a study involving adolescents from 25 countries, prevalence of being bullied and bullying others were found to be $11 \%$ and $10 \%$ respectively with poorer psychosocial adjustment in victims, bullies and bully-victims (4). The prevalence of obesity is increasing worldwide and can result in adverse health outcomes later in life. The seeds to this problem seem to be sewn in adolescence with decreasing physical activity (2), increasing sedentary activity (5) and unhealthy nutritional food choices (6) being seen. A cohort study showed an overall increase in new alcohol and cigarette users in higher age groups with varying percentage increase moving from different stages (7). While another showed these habits becoming riskier and adolescents becoming less reluctant to cease with age (8). Mental disorders occur in about 1 out of 5 adolescents (9), with early onset of depression leading to outcomes such as later depression, reduced likelihood of entering a university and suicidal behavior in later adolescence (10).

Pakistan is one of the most populous countries in the world with a large portion of this being within the adolescent age group. Little work has been done to assess their behavioural status and effort must be put in to identify areas of concern so appropriate interventions can be undertaken.

\section{Methodology}

A cross sectional study was performed in 2 schools of Karachi.

A self-administered questionnaire was developed which included 28 questions on the following categories; eating 
habits, exercise, aggressive behaviour, hygiene, internet use, studying habits and tobacco use.

Ethical approval was obtained from the Ethical Review Board at Ziauddin University.

Students of classes 6th, 8th and 10th were included in the study. Permission was obtained from the principal of the respective schools. The purpose of the study was explained to the students in the classroom and questionnaire was distributed to the students after obtaining verbal consent.

Data was analyzed using IBM SPSS version 20.

Results:

A total of 603 students from 2 schools participated in the study. 290 students were from school Aand 313 students from school B. 191 students were from grade 6, 197 students from grade 8 and 215 students from grade 10 .

In general eating habits became more unhealthy going from class 6 to class $10.89 .5 \%$ of students in grade 6 ate breakfast daily. This number decreased to $79.8 \%$ and further decreased to $64.7 \%$ amongst students of grade 8 and grade 10 respectively. Similarly decreasing trends were seen with regards to daily consumption of vegetables, fruits and milk as indicated in figure 1.0. Conversely daily consumption of junk food increased from $36.6 \%$ in grade $6,38.1 \%$ in grade 8 and $47.4 \%$ in grade 10 . Similarly increasing trend was seen in daily consumption of carbonated beverages also shown in table 1.0.

Table 1. Percentage of eating habits of students in different grades

\begin{tabular}{|l|l|l|l}
\hline Eating Habit & Grade 6 & Grade 8 & Grade 10 \\
\hline $\begin{array}{l}\text { 1. Daify } \\
\text { breakfast } \\
\text { consumption }\end{array}$ & $89.5 \%$ & $79.7 \%$ & $64.7 \%$ \\
\hline $\begin{array}{l}\text { 2. Daily } \\
\text { vegetable } \\
\text { consumption }\end{array}$ & $31.4 \%$ & $17.8 \%$ & $9.8 \%$ \\
\hline $\begin{array}{l}\text { 3. Daily fruit } \\
\text { consumption }\end{array}$ & $59.7 \%$ & $50.8 \%$ & $34.9 \%$ \\
\hline $\begin{array}{l}\text { 4. Daily junk } \\
\text { food } \\
\text { consumption }\end{array}$ & $36.6 \%$ & $38.1 \%$ & $47.4 \%$ \\
\hline $\begin{array}{l}\text { 5. Daily } \\
\text { carbonated } \\
\text { beverage } \\
\text { consumption }\end{array}$ & $20.4 \%$ & $16.2 \%$ & $37.2 \%$ \\
\hline $\begin{array}{l}\text { 6. Daily milk } \\
\text { consumption }\end{array}$ & $74.3 \%$ & $60.9 \%$ & $42.8 \%$ \\
\hline
\end{tabular}

Physical activity saw a decreasing trend with $34.0 \%$ of students in grade 6 exercising more than 2 hours a day while this decreased to $19.4 \%$ in grade 8 and $16.9 \%$ in grade $10.13 .1 \%$ of students in grade 6 said they did not have time for exercise while this increased to $17.3 \%$ in grade 8 and further increases to $28.2 \%$ in grade 10 .

Almost all students washed their hands before eating meals and after using the bathroom. $50.3 \%$ of students in grade 6 brushed their teeth twice daily while $40.3 \%$ in grade 8 and $33.3 \%$ in grade 10 did so.

Internet use increases with students in grade 10 spending more time on the internet than students in grades 6 and 8 . Internet use more than 2 hours/day was seen in $12.6 \%$ of students in grade $6,13.8 \%$ in grade 8 and $28.6 \%$ in grade 10 . This use seems to be more for unproductive purposes especially in students in higher grades as shown in table 2.0.

Table 2. Percentage use of internet among students of different grades

\begin{tabular}{|l|l|l|}
\hline Grade & $\begin{array}{l}\text { Most common } \\
\text { use of internet }\end{array}$ & $\begin{array}{l}2^{\text {nd }} \text { most } \\
\text { common use } \\
\text { of internet }\end{array}$ \\
\hline 1. Grade 6 & $\begin{array}{l}\text { Play games } \\
(31.9 \%)\end{array}$ & $\begin{array}{l}\text { Get information } \\
(23.0 \%)\end{array}$ \\
\hline 2. Grade 8 & $\begin{array}{l}\text { Get information } \\
(25.0 \%)\end{array}$ & $\begin{array}{l}\text { Socializing } \\
(19.4 \%)\end{array}$ \\
\hline 3. Grade 10 & $\begin{array}{l}\text { Socializing } \\
(38.0 \%)\end{array}$ & $\begin{array}{l}\text { Entertainment } \\
(21.6 \%)\end{array}$ \\
\hline
\end{tabular}

Parents' involvement in their children's education saw decreasing trends. $91.1 \%$ and $91.3 \%$ of children in grade 6 and grade 8 received help from parents respectively while this decreased to $78.4 \%$ in class $10.58 .6 \%$ of those in grade 6 who received help from parents got help daily while this decreases to $52.0 \%$ in grade 8 and $30.0 \%$ in grade $10.73 .3 \%$ students in grade 6 read other books apart from their school curriculum while $66.3 \%$ in grade 8 and $46.9 \%$ in grade 10 did the same.

Aggressive behaviour increased the higher the grade the student was in. $16.2 \%$ of children in grade 6 were involved in a fight a few times a year while $26.0 \%$ in grade 8 and $23.5 \%$ in grade 10 . Conversely $73.3 \%$ of children in class 6 were never involved in a fight while $56.1 \%$ in grade 8 and $60.1 \%$ in grade 10 .

Tobacco use also increased amongst students in higher grades. Only 1 person in grade 6 used cigarettes while $10(5.1 \%)$ in grade 8 and $24(11.3 \%)$ in grade 10 were involved in cigarette smoking. $3.1 \%$ of students in grade 6 used sheesha while this increased to $9.2 \%$ in grade 8 and $22.1 \%$ in grade 10 . Beetle nut use also increased with $4.2 \%$ of students in grade 6 being users while $10.2 \%$ in grade 8 and $11.3 \%$ in grade 10 respectively.

\section{Discussion}

As indicated by previous studies adolescent behaviour seems to be becoming more unproductive as adolescents progress through school. Unhealthy eating habits, decreased physical activity and increased risky behaviour were seen in adolescents in higher grades. Some of this behaviour appears to get progressively worse as the student progresses through school while 
others occur at specific times.

Uniformly progressive decreasing trends were seen in categories of daily consumption of breakfast, vegetables, fruit and milk and reading books apart from school curriculum. Uniformly progressive increasing trends were seen in cigarette and sheesha smoking.

Significant changes moving from grade 8 to grade 10 were seen in increased daily carbonated beverage consumption, increased daily junk food consumption and increased use of internet for more than 2 hours/day while decreased parental involvement in their children's studying was also seen. Significant changes moving from grade 6 to 8 were seen in increased beetle nut use and decreased physical activity.

Previous studies have shown that modifiable risk factors exist for some of these behavioural changes. Parents spending more time with their children and communicating with them more frequently were identified as protective factors in the development of tobacco use (8). In contrast media influence (11) and having parents or peers who smoke (12) led to increased tobacco experimentation. Preventing the development of such activity early on is important as older adolescents have been shown to become more reluctant to relinquish these habits (12).

Interventions have been show to modify adolescent behaviour with regards to smoking (13) and increasing physical activity (6). Such interventions need to be designed and implemented at provincial and national levels to reverse the status quo currently being seen.

\section{References}

1. www.who.int/maternal_child_adolescent/ topics/adolescence/dev/en

2. Dumith S, Gigante D, Domingues M, Kohl III H. Physical activity change during adolescence: a sytematic review and a pooled analysis. Int. J. Epidemiol. 2011;40(3):685-698. doi: 10.1093/ije/dyq272

3. Fombonne E, Wostear G, Harrington R. The Maudsley long-term follow-up of child and adolescent depression. The British Journal of Psychiatry. 2001;179:210-217. doi: 10.11929/bjp.179.3.210

4. Nansel TR, Craig W, Overpeck MD, Saluja G, Ruan J.Cross-national Consistency in the Relationship Between Bullying Behaviors and Psychosocial Adjustment. Arch Pediatr Adolesc M e d. $2004 ; 158$ ( 8 ) : $730-736$. doi:10.1001/archpedi.158.8.730

5. Nelson MC, Neumark-Stzainer D, Hannan PJ, Sirard JR, Story M. Longitudinal and Secular Trends in Physical Activity and Sedentary Behavior During Adolescence. Pediatrics 2006, December, $1 ; 118$ (6) : $1627-1634$. doi:10.1542/peds.2006-0926

6. Nader PR, Stone EJ, Lytle LA, Perry CL, Osganian SK, Kelder S, et al. Three-Year
Maintanance of Improved Diet and Physical Activity The CATCH Cohort. Arch Pediatr Adolesc Med. 1999;153(7):695-704. doi:10.1001/archpedi.153.7.695

7. Cohen DA, Richardson J, LaBree L. Parenting Behaviors and the Onset of Smoking and Alcohol Use: ALongitudinal Study. PEDIATRICS 1994, September, 1; 94(3):368-375

8. Kelder SH, Perry CL, Klepp KI, Lytle. Longitudinal tracking of adolescent smoking, physical activity, and food choice behaviors. Am J Public Health 1994, July; 87(8):1121-1126

9. Costello EJ, Copeland W, Angold A. Trends in psychopathology across the adolescent years: What changes when children become adolescents, and when adolescents become adults? J Child Psychol Psychiatry. 2011;52(10):1015-1025. doi: 10.1111/j.14697610.2011.02446.x

10. Fergusson DM, Woodward LJ. Mental Health, Educational and Social Role Outcomes of Adolescents With Depression. Arch Gen Psychiatry. 2002;59(3):225-231. doi:10.1001/archpsyc.59.3.225

11. Sargent JD, Beach ML, Dalton MA, Mott LA, Tickle JJ, Ahrens BM, et al. Effect of seeing tobacco use in films on trying smoking among adolescents: cross sectional study. BMJ 2001;323:1394

12. Cai Y, Lu L, Li na, Zhu J, He Y, Redmon P, et al. Social, Psychological, and EnvironmentalStructural Factors Associated with Tobacco Experimentation among Adolescents in Shanghai, China. Int J Environ Res Public Health. 2012;9(10):3421-3436. doi: 10.3390/ijerph9103421

13. Bruvold WH. A meta-analysis of adolescent smoking prevention programs. American Journal of Public Health. 1993 Jun;83(6):872-80. 